\title{
The Powerful Antitakeover Force of Staggered Boards: Further Findings and a Reply to Symposium Participants
}

\author{
Lucian Arye Bebchuk, * John C. Coates IV** \& \\ Guhan Subramanian***
}

This Reply develops and defends our earlier analysis of the powerful antitakeover force of staggered boards. We reply to five responses to our work, by Stephen Bainbridge, Mark Gordon, Patrick McGurn, Leo Strine, and Lynn Stout, which are published in this Symposium. We present new empirical evidence that extends our earlier findings, confirms our conclusions, and demonstrates that the alternative theories put forward by some commentators do not adequately explain the evidence. Among other things, we find that having a majority of independent directors does not address the concern that defensive tactics might be abused. We also find that "effective" staggered boards do not appear to have a significant beneficial effect on premiums in negotiated transactions. Finally, we show that, unlike our approach, the approach that our critics advocate for Delaware takeover jurisprudence to follow is both inconsistent with its established principles and takes an extreme position in the overall debate on takeover defenses. Our analysis and new findings further strengthen the case for limiting the ability of incumbents armed with a staggered board to continue saying no after losing an election conducted over an acquisition offer.

* William J. Friedman and Alicia Townsend Friedman Professor of Law, Economics, and Finance, Harvard Law School; Research Associate, National Bureau of Economic Research and Center for Economic Policy Research.

** Professor of Law, Harvard Law School.

*** Joseph Flom Assistant Professor of Law and Business, Harvard Law School. We thank Tara Abbatello, Alastair Brown, and Lubov Getmansky for excellent research assistance and Jeff Gordon for helpful discussions. We also wish to thank the Harvard Law School and the Harvard John M. Olin Center for Law, Economics, and Business for their financial support. 


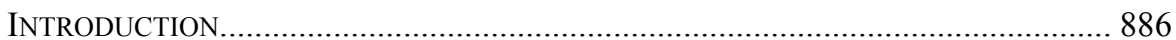

I. THE EFFeCt OF ESBS ON THE OUtCOMES OF HostiLE BIDS ............................ 888

A. The Welcome Concession of Defense Proponents .............................. 889

B. The Effect of Independent Directors .................................................. 891

1. Case study: Union Pacific's hostile bid for Pennzoil. .......................... 891

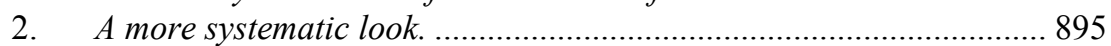

C. The Uneasy Case for Absolute Reliance on Independent

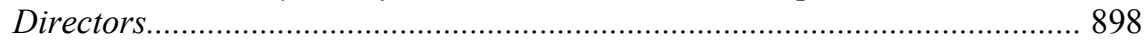

D. Implications for Current Corporate Governance Reforms................. 900

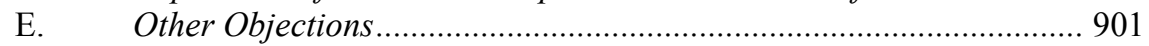

II. COUNTERVAILING BENEFITS IN FRIENDLY ACQUISITIONS.................................. 904

A. Do ESBs Necessarily Increase Premiums in Friendly

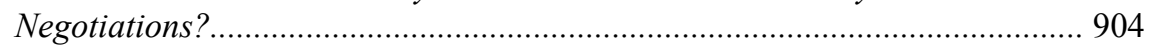

B. The Poison Pill "Evidence"......................................................... 905

C. New Evidence on the Higher Premiums Hypothesis ........................... 906

D. Case Study: Weyerhaeuser's Hostile Bid for Willamette ................... 908

III. OUR PROPOSED APPROACH......................................................................... 909

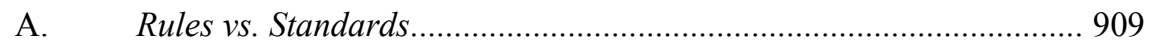

B. Judicial Moderation ....................................................................... 911

C. The Extreme Positions of Our Critics............................................... 912

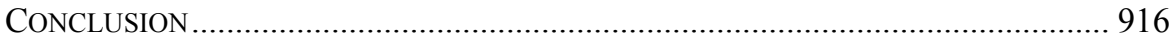

\section{FIGURES}

Figure 1: Value of One Pennzoll Share, Jan. 1997-Dec. 2001..................... 893

FIGURE 2: BOARD COMPOSITION FOR TARGETS THAT REMAINED

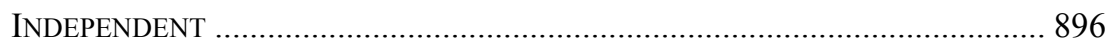

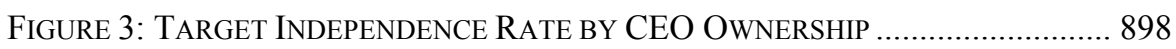

Figure 4: SHORT-Run BID OutCOMES, DElawARE TARGETS ONLY .................. 903

FIgURE 5: MEdiAN BID PREMIUM By TARGET DEFENSES ................................... 907

FiguRE 6: CONTINUUM OF VIEWS ON TAKEOVER DEFENSES ........................... 914

\section{INTRODUCTION}

Earlier this year in the Stanford Law Review, we presented a theoretical, empirical, and policy analysis of staggered boards. ${ }^{1}$ We argued that "effective" staggered boards (ESBs) provide a powerful antitakeover defense, more powerful than is commonly recognized. We developed a theoretical account of how ESBs impede hostile takeover bids, and tested our theory using a new data set of hostile bids from 1996 to 2000.

Our empirical analysis provided three findings. First, targets with ESBs were substantially more likely to remain independent than targets without ESBs. Second, targets in our sample that remained independent did not, on

1. See Lucian Arye Bebchuk, John C. Coates IV \& Guhan Subramanian, The Powerful Antitakeover Force of Staggered Boards: Theory, Evidence, and Policy, 54 STAN. L. REV. 887 (2002). 
average, achieve on their own the same returns as offered by the hostile bidder or white knight. Third, ESBs did not seem to provide countervailing benefits in the form of higher premiums in deals that were eventually completed. Putting these three findings together, we found that ESBs reduced shareholder returns for targets in our sample on the order of eight to ten percent in the nine months after a hostile bid was announced. Based on these findings and our analysis of Delaware takeover case law, we proposed that, at least absent explicit shareholder authorization to the contrary, incumbents protected by an ESB who lose one election over an outstanding bid should generally not be allowed by courts to further block the bid by maintaining a poison pill.

This issue of the Stanford Law Review includes five commentaries that present responses and reactions to our article. We are delighted by the range of views represented by the authors. Mark Gordon, our strongest critic, is a practicing lawyer and a partner of Wachtell, Lipton, Rosen \& Katz, the firm credited with inventing the poison pill. Steve Bainbridge and Lynn Stout are academics who have been writing on takeovers and corporate governance from perspectives quite different from our own. Patrick McGurn, as Special Counsel for Institutional Shareholder Services, is a direct participant in most takeover battles and has an excellent perspective on the views of institutional investors. Finally, Vice Chancellor Leo Strine of the Delaware Chancery Court represents an important audience for our work, as it is the Delaware judiciary whose future interpretation of takeover doctrine we seek to influence. We thank all of these commentators for their thoughtful and provocative responses.

While none of the commentators challenge either our theoretical account of how ESBs work as a takeover defense, or the three basic empirical findings that are summarized above, all of them, to varying degrees, raise important questions, objections, and areas of further inquiry regarding our analysis and conclusions. In this Reply, we respond to these points. In the course of our discussion, we extend our earlier work, and present new data that shed additional light on the issues raised. As there is some overlap among the commentaries, we structure our discussion by substantive issue rather than by commentator.

In Part I, we first note an important shift in the debate that this Symposium represents, with takeover proponents no longer claiming that defenses increase shareholder value for hostile bid targets from an ex post perspective. We believe that this acceptance of our basic findings, in itself, represents an important victory for our work. We then discuss claims concerning the outcomes of hostile bids, which has been the focus of our empirical inquiry. In particular, we provide new evidence to address the objection that, although the boards that remained independent in the face of hostile bids reduced shareholder value, on average, the cases studied were likely ones in which the board did not have independent directors or was dominated by the CEO. To examine this claim, we gather evidence on the composition of boards in our study and find that they do not stand out in the conjectured way. Rather, while 
many of the targets in our data set had a majority of independent directors, these targets did not perform considerably better in serving shareholder interests. This finding suggests that the absolute confidence that our critics would place in independent directors is unwarranted.

Part II discusses the claim that, even if ESBs hurt shareholders in hostile bid situations, they benefit shareholders in friendly transactions by increasing managers' ability to obtain a high premium. While we have documented the considerable adverse effect of ESBs on hostile bid outcomes, their effect on negotiated transactions remains very much an open question. Given that supporters of defenses have failed to produce any reliable evidence on the effects of ESBs (and defenses more generally) on negotiated premiums, we conduct some preliminary tests. Examining a sample of seventy-three negotiated transactions from 2000 to 2002, we find no systematic benefits in terms of higher premiums to boards that have ESBs. We conclude that, under current evidence, the speculated benefits of ESBs in friendly transactions do not justify the current role of ESBs in light of their other clear negative effects.

Part III discusses claims concerning the approach we propose courts should follow. Accepting the suggestions by Vice Chancellor Strine and others that standards better fit the general approach of the Delaware courts, we show how our approach could, and indeed should, be formulated as a standard. Under the proposed standard, if a board has lost an election conducted over an outstanding offer, maintaining the pill further should be presumed disproportionate or preclusive, but the target board should have an opportunity to persuade a court that its reasons for maintaining a pill were justified by unusual facts or circumstances. We also discuss how adoption of our approach by the Delaware courts would be consistent with a judicial approach that is cautious and evolutionary. We finally point out that the positions advocated by our critics are ones that are extreme both within their location on the continuum of choice and in terms of their departure from established principles. We conclude that, given the current body of theory and evidence, our approach is best both in terms of its substantive effects and in terms of its fit with notions of legitimacy and consent.

\section{THE EFFECT OF ESBS ON THE OUtCOMES OF HostILE BIDS}

In this Part, we address the criticisms of our core empirical result, involving the effect of ESBs on hostile bid outcomes. In Part I.A, we first note, as a rhetorical matter, an important shift in the debate, one that concedes a considerable amount of the ground that prior defenders of a board-centered approach refused to concede. In Part I.B, we move on to the first of two substantive criticisms of our study, put forward primarily by Gordon, that factors other than ESBs might be responsible for the results that we find. Though the possibility of omitted variables applies to any empirical study, and the effort to include all possible control variables is thus never-ending, we 
oblige Gordon and respond directly to each of the possibilities about which he speculates. In Part I.B, we address his primary concern that bad boards, not ESBs, are responsible for bad outcomes. In fact, we provide new evidence showing that bad outcomes are not exclusively caused by nonindependent boards or boards dominated by the CEO. Instead, the phenomenon we report in our original paper is far broader than pathological instances of unusually dysfunctional boards. In Parts I.C and I.D, we discuss some implications of these findings, first for the specific issues raised in this Symposium, and then for the recent corporate governance reforms in the Sarbanes-Oxley Act of 2002 and in the New York Stock Exchange revised listing guidelines. Finally, in Part I.E, we report the results on other factors that Gordon identifies, such as Delaware incorporation, bear hug bids, and our distinction between effective annual term (EAT) targets and ESB targets. Here again the evidence supports our core finding that ESBs are the primary driver of bad outcomes.

\section{A. The Welcome Concession of Defense Proponents}

We begin with the observation that none of the commentators who are critical of our study challenge our basic findings that ESBs allow hostile bid targets to remain independent and that, by enabling hostile bid targets to remain independent, ESBs are, on average, detrimental ex post to target shareholders. Instead of a direct attack, these commentators make collateral attacks in the form of alternative explanations for our results, or speculate about countervailing benefits of ESBs. Before moving on to these specific points, we wish to point out that these arguments already represent an important shift in the debate with respect to takeover defenses. By more or less accepting our conclusion that incumbents' ability to just say no hurts shareholders in hostile bid situations, our critics have conceded a great deal of the ground that takeover defense proponents in the past have refused to yield. This implicit concession is therefore important to highlight; in itself it represents an important victory for our work.

For example, Lynn Stout kindly acknowledges that our empirical findings "do a nice job of undermining the argument that [takeover defenses] increase target shareholders' ex post returns." 2 Steve Bainbridge accepts this result but somewhat remarkably responds "so what?"3 Even Gordon, a member of the firm that is most associated with the development of takeover defenses in general, and the poison pill in particular, does not question our finding that ESBs have overall hurt the shareholders of hostile bid targets, but only claims

2. Lynn A. Stout, Do Antitakeover Defenses Decrease Shareholder Wealth? The Ex Post/Ex Ante Valuation Problem, 55 StAN. L. ReV. 845, 856-57 (2002).

3. Steven M. Bainbridge, Director Primacy in Corporate Takeovers, 55 STAN. L. REV. 791, 807 n.92 (2002). 
that this adverse effect is far outweighed by the benefits of ESBs in cases of friendly acquisitions. ${ }^{4}$

We find these concessions interesting for at least two reasons. First, defenders of board veto and takeover defenses have long avoided making such a concession and have taken the view that, in those cases in which bids are defeated by takeover defenses, shareholders are by and large made better off. That is, the more common view has been that target boards' decisions to remain independent, implemented through takeover defenses, generally benefit shareholders. For example, Gordon's partner Martin Lipton argued as early as 1979 that "[e]xperience shows that ... the shareholders have profited in the overwhelming majority of defeated takeovers." 5

In recent exchanges, Lipton continues to maintain this strong view. ${ }^{6}$ The evidence we have put forward, however, indicates that it is no longer possible for Lipton and others to maintain such a view. In fact, we show that defeating hostile bids (at least in the five years that we study) not only does not profit shareholders in the "overwhelming majority" of cases, but commonly hurts them. It is for this reason that we highlight the point that none of the supporters of the board veto in this Symposium repeats the claim that shareholders benefit in those cases in which hostile bids are defeated. By not questioning the ex post costs of ESBs for hostile bid targets, Bainbridge, Stout, and Gordon concede the ground that Lipton was unwilling to give up.

A second implication for this "new school" among takeover defense proponents is that it creates an important tension with existing principles of Delaware's takeover jurisprudence. Delaware law has allowed the use of defensive tactics only to the extent that such tactics are expected to benefit shareholders in the particular case in which they are used. ${ }^{7}$ If defensive tactics hurt shareholders in the particular case, they cannot be justified within existing Delaware law by appealing to other effects. Because Bainbridge, Stout, and Gordon resort to such other effects, their approaches are quite different from the one that the Delaware courts have repeatedly expressed; in examining whether a defense employed by a hostile bid target is permissible, the Delaware courts have generally focused on whether it would benefit the shareholders of

4. Mark Gordon, Takeover Defenses Work. Is That Such a Bad Thing?, 55 STAN. L. REV. 819, 823, 837 (2002).

5. Martin Lipton, Takeover Bids in the Target's Boardroom, 35 Bus. LAw. 101, 10809 (1979) (emphasis added).

6. See, e.g., Martin Lipton \& Paul K. Rowe, Pills, Polls and Professors: A Reply to Professor Gilson, 27 DEL. J. CORP. L. (forthcoming 2002), available at http://papers.ssrn.com/paper.taf?abstract_id=268520.

7. See, e.g., Revlon, Inc. v. MacAndrews \& Forbes Holdings, Inc, 506 A.2d 173, 185 (Del. 1986) ("The initial defensive tactics worked to the benefit of the shareholders, and thus the board was able to sustain its Unocal burden in justifying those measures."). See also Unocal Corp. v. Mesa Petroleum Co., 493 A.2d 946 (Del. 1985); Paramount Communications, Inc. v. Time Inc, 571 A.2d 1140 (Del. 1989); Moran v. Household Int'l, Inc., 500 A.2d 1346 (Del. 1985). 
Dec. 2002]

the target in question and not on the potential benefit that such a tactic might have for other companies. To be sure, from a policy perspective, all effects are relevant and should be considered in an examination from first principles. But it is worthwhile highlighting for the Delaware courts that all commentators in this Symposium appear ready to admit that, more often than not, defenses hurt the shareholders of hostile bid targets that remain independent.

\section{B. The Effect of Independent Directors}

Gordon states that "[e]xperience suggests that boards that are truly independent of senior management and other insiders ultimately "do the right thing' and ... find the best deal for stockholders," that we will find that any truly abusive behavior is closely associated with boards that are not truly independent and outside." 9 Gordon does not provide any nonanecdotal evidence for this "suspicion." In this section, we nevertheless take Gordon's assertion at face value and test the hypothesis that bad boards are responsible for bad outcomes. In Part I.B.1, we present a case study that provides one counterexample, in fact quite a strong one, that target boards that remain independent are not in fact all bad apples. In Part I.B.2, we present more systematic evidence showing that targets that remain independent are not dominated by insiders, large-block CEO shareholders, or both. Putting these findings together, it becomes clear that Gordon's "suspicion" from "experience" is not supported by the evidence; thus his policy proposal to rely more heavily on independent boards (which he shares with Bainbridge and Stout) seems unwarranted.

\section{Case study: Union Pacific's hostile bid for Pennzoil.}

We begin with a concrete case study-Union Pacific's hostile bid for Pennzoil-which provides a powerful counterexample to Gordon's suspicion that bad outcomes are due to bad boards. Union Pacific Resources Group (UPR), the largest independent energy exploration company in the United States, launched an unsolicited bid to acquire Pennzoil in June 1997. The proposed consideration was $\$ 84$ per share in cash for $53 \%$ of the shares, to be followed by a second-step exchange offer for UPR stock also valued at $\$ 84$ per share. The offer represented a $41 \%$ premium over Pennzoil's share price immediately before the bid and a 55\% premium over Pennzoil's share price four weeks prior to the bid.

According to SEC filings, UPR began its hostile bid only after Pennzoil had rebuffed friendly overtures. In a letter from Pennzoil Chairman and CEO James L. Pate to UPR CEO Jack Messman sent in May 1997, the Pennzoil

8. Gordon, supra note 4, at 831.

9. Id. at 833 . 
CEO emphatically stated, "I thought I had made it plain that Pennzoil fully intends to remain independent and is not interested in engaging in any process that could put Pennzoil into play."10 And in response to the bid one month later, Pate reiterated that " $[\mathrm{t}] \mathrm{his}$ is not the time to sell the company, to Union Pacific or anybody... . That position is very solid." 11 Indeed, ten days after UPR made its offer public, the Pennzoil board unanimously rejected UPR's bid. ${ }^{12}$

Bolstering this position were Pennzoil's takeover defenses. Pennzoil had in place the pill-ESB combination which, as we argued in our original paper, provided it with an extremely potent set of defenses. Pennzoil's staggered board was specified in its charter, ${ }^{13}$ directors could be removed only with cause, ${ }^{14}$ and newly created directorships could only be filled by the remaining directors. ${ }^{15}$ In addition, Pennzoil had just held its annual meeting in April 1997, meaning that UPR would have to wait another nine months before it could launch even a first proxy contest to gain one-third of the seats on Pennzoil's board. 16 These defenses led the Wall Street Journal to conclude that "Union Pacific Resources must have a negotiated transaction."17

By October 1997, three months after the initial bid was launched, UPR had changed its bid to an $\$ 84$ per share all-cash offer, and $61 \%$ of Pennzoil shareholders had tendered into the offer. Still the Pennzoil board continued to resist, not out of any stated concern for other constituencies, but, at least publicly, out of a belief that shareholders would benefit - in other words, the classic argument now conceded to be wrong, on average, by all participants in this Symposium. According to the Journal, "[Pennzoil] said its board believes shareholders will benefit more from its efforts to improve its earnings and future performance than they will from tendering their shares to Union Pacific Resources."18 Of course, some analysts disagreed. "I'm flabbergasted," said one. "It makes me wonder if what's really at issue is value."19 And noted shareholder activist Guy Wyser-Pratte, whose arbitrage fund held 1\% of

10. See Steven Lipin, Allanna Sullivan \& Terzah Ewing, In Fight for Pennzoil, Old Suitor Becomes the Pursued, WALl ST. J., June 24, 1997, at B4 (quoting Pate's letter).

11. See Peter Fritsch \& Steven Lipin, Pennzoil's Board Urges Holders to Reject Union Pacific Resources' Takeover Bid, WALL St. J., July 2, 1997, at A4 (quoting Pate).

12. See id.

13. Pennzoil Co. Restated Certificate of Incorporation, art. III, § 2 (May 3, 1995).

14. Id. art. III, $\S 3$.

15. Id. art. III, $\S 4$.

16. See Pennzoil Proxy Statement, Mar. 21, 1997 (stating agenda for annual meeting to be held on April 24, 1997).

17. See Steven Lipin, Union Pacific Resources Bids for Pennzoil, Wall St. J., June 23, 1997, at A3.

18. Pennzoil Board Spurns Union Pacific Offer, Sues in Federal Court, Wall St. J., Oct. 15, 1997, at B8.

19. Id. (quoting Arthur Tower III, analyst, Howard Weil Labouisse Friedrichs, Inc.). 
Dec. 2002]

Pennzoil shares, argued, "How can the company say it's not for sale when $61 \%$ of us said we are for sale even before the offer became all cash?"20

Faced with Pennzoil's opposition, UPR withdrew its offer in November 1997. As we show in our original paper, this is the typical outcome against a pill-ESB combination. ${ }^{21}$ Figure 1 shows the value of one share of Pennzoil from January 1997, six months before UPR's bid was announced, to December 2001.22

Figure 1: VAlue of ONe Pennzoil Share, Jan. 1997-DeC. 2001.

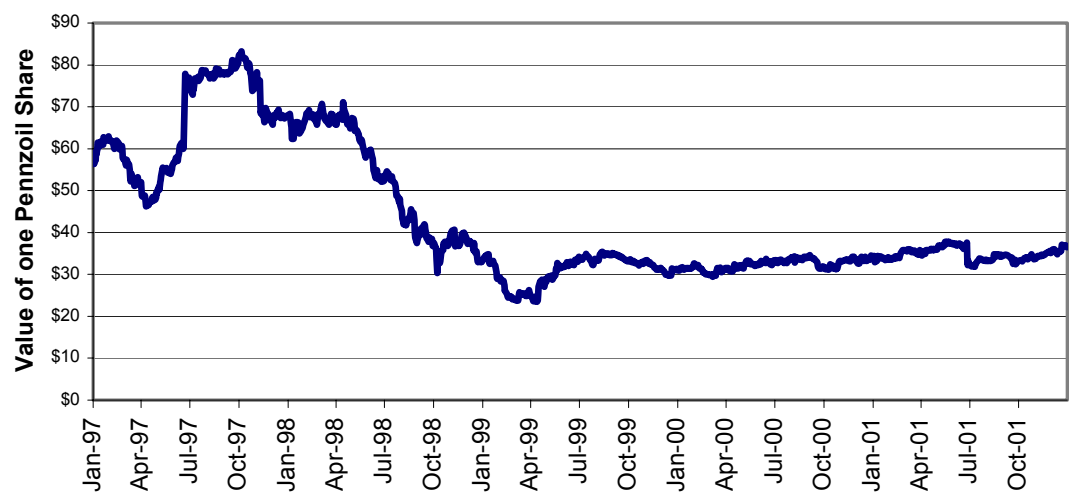

As shown, once UPR withdrew its offer, the value of one Pennzoil share dropped to approximately $\$ 35$ for the next thirty months. During this same period, the S\&P 500 index increased by $52 \%{ }^{23}$ In April 1998, Pennzoil merged with Quaker State and spun off PennzEnergy to Pennzoil shareholders. In August 1999, PennzEnergy was sold to Devon Energy for $\$ 18$ per share in stock. In October 2002, the remaining pieces of Pennzoil that were part of Pennzoil-Quaker State were acquired by Shell Oil for $\$ 22$ per share in cash. Thus, all in all, Pennzoil shareholders received by October 2002 approximately $\$ 40$ per share, ${ }^{24}$ less than half of what UPR offered in June 1997 . Using a (conservative) 6\% discount rate, Pennzoil's defense against UPR destroyed $\$ 2.0$ billion dollars for its shareholders. ${ }^{25}$ Using a discount rate closer to a

20. Id.

21. See Bebchuk et al., supra note 1, at 930 fig.3, 933 fig.4.

22. Data comes from the Center for Research in Securities Prices (CRSP) database. These calculations include dividends and the value of one PennzEnergy share, which was the oil-and-gas exploration and production company that Pennzoil left as a stand-alone entity after merging with Quaker State in December 1998.

23. The S\&P 500 Index increased from 955 in November 1997 to 1452 in April 2000.

24. The $\$ 40$ per share value consists of $\$ 18$ per share of Devon Energy stock and $\$ 22$ per share of cash from Shell Oil.

25. This calculation assumes that shareholders sold their Devon Energy stock when 
market rate of return would yield an even larger estimate of the value destroyed by Pennzoil's defenses.

Gordon's position suggests that Pennzoil's directors must be bad apples: "My suspicion is that we will find that any truly abusive behavior is closely associated with boards that are not truly independent and outside...."26 To test this hypothesis, we analyzed the profiles of the eleven directors who were on the Pennzoil board in June 1997, at the time that UPR's bid was announced. Using the best available objective definition of inside, outside, and gray directors, ${ }^{27}$ we find that all but one of Pennzoil's eleven directors were outside, or independent, directors. ${ }^{28}$ The one insider on the board was James Pate, the CEO. Among the outsiders were Howard Baker, former United States Senator and White House Chief of Staff, and Brent Scowcroft, former National Security Advisor to the President, both of whom would have enormous reputational capital at stake in being on the Pennzoil board. While it would be difficult to know what the interpersonal dynamics of the Pennzoil board were at the time, it seems unlikely that Pate would have been able to dominate these eminent public figures. Far from being unusual, much less pathological (as Gordon predicts), this board would seem to be able to operate independently from management. And yet the board voted, not once but twice - after the original UPR bid and again after it was made into an all-cash offer- to reject the bid, against the preference of a majority of the shareholders. In the next Part, we show that the Pennzoil case is not an exception, and that, in fact, targets that remain independent do not have the kind of pathological boards that Gordon speculates about.

that deal closed, and that all cash received in the Devon Energy acquisition, the Shell Oil acquisition, and the hypothetical Union Pacific Resources acquisition would be reinvested at the risk-free rate (assumed to be $6 \%$ ).

26. See Gordon, supra note 4, at 833.

27. David Yermack defines "inside" directors as "board members who are current or former officers of [the] company." See David Yermack, Higher Market Valuation of Companies with a Small Board of Directors, 40 J. Fin. ECON. 185, 191 tbl.1 (1996). "Gray" directors are board members "who have substantial business relationships with the company, either personally or through their main employers, and also relatives of corporate officers." Id. "Outside" directors are board members "who have neither inside nor gray status." Id.

28. The ten outside directors, as described in Pennzoil's 1997 proxy statement were: Howard Baker, Jr. (former United States Senator and Chief of Staff to the President); Harry Cullen (independent businessman engaged in oil and gas exploration and production); Gerald Smith (Chairman and CEO of his own fixed income investment management firm); W.J. Boviard (Chairman of his own investment company); W.L. Lyons Brown, Jr. (former Chairman and CEO of Brown-Forman Corp., a diversified producer and marketer of consumer products); Ernest Cockrell (independent businessman engaged in oil and gas exploration and production); Alfonso Fanjul (Chairman \& CEO of Flo-Sun Inc., a sugar and real estate company); Berdon Lawrence (President of Hollywood Marine, an operator of tank barges and tow boats that handle petrochemical and petroleum products); Brent Scowcroft (former National Security Advisor to the President); and Cyril Wagner (partner in a firm engaged in oil and gas exploration and production). Pennzoil Co. Proxy Statement $\S 1$, at 47 (filed Apr. 24, 1997). 
Dec. 2002]

\section{A more systematic look.}

So far we have presented a single case study illustrating the point that not all target boards that do the wrong thing for shareholders are captive to management. Therefore, at the very least, the bad board hypothesis cannot provide a complete explanation for targets that remain independent. Though his argument appears to be quite categorical, ${ }^{29}$ Gordon might argue in response, when faced with this evidence, that Pennzoil is an anomaly-that is, targets that remain independent generally have bad boards, but that we are bound to find one or two good boards among the bad boards that collectively do the wrong thing for shareholders. In this section, we present more systematic evidence that rejects this claim as well.

Targets remaining independent not dominated by management directors. We begin with the same sample of all hostile bids from 1996 onward as reported in our original paper, updated since then to include more recent bids ( $\mathrm{n}=112$ total bids). ${ }^{30}$ We then focus on the subset of targets that remained independent nine months after the hostile bid was launched $(\mathrm{n}=55)$ and targets that remained independent thirty months after the hostile bid was launched $(\mathrm{n}=41)$. We analyze the composition of these boards, using the proxy statement immediately before the hostile bid was launched to identify and categorize the directors. As in the previous section, we follow David Yermack's definitions for "inside," "outside," and "gray" directors. ${ }^{31}$ Figure 2 shows the average board composition of these targets, divided between ESB and non-ESB targets, for targets that remained independent nine months after the hostile bid was launched:

29. See Gordon, supra note 4, at 833 ("My suspicion is that we will find that any truly abusive behavior is closely associated with boards that are not truly independent and outside ...." (emphasis added)).

30. When we add these new bids to our data set, none of the findings or conclusions from our original article change in any significant way. We report the results from our larger sample in a current work-in-progress. See Lucian Arye Bebchuk, John C. Coates IV \& Guhan Subramanian, The Effect of Takeover Defenses (Oct. 25, 2002) (unpublished manuscript, on file with authors).

31. See supra note 27. 
FIGURE 2: BOARD COMPOSITION FOR TARGETS THAT REMAINED INDEPENDENT

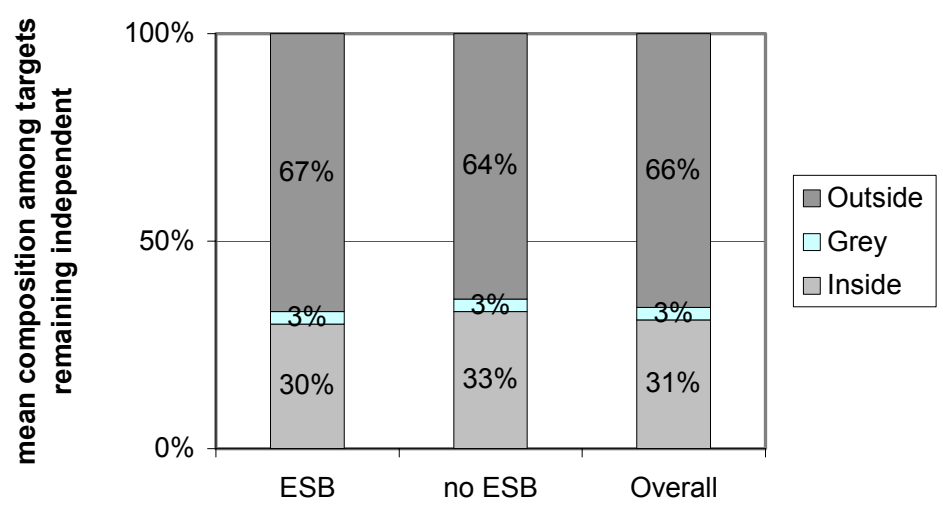

Figure 2 shows that of takeover targets that remain independent nine months after the hostile bid was launched, $67 \%$ of directors of ESB targets and $64 \%$ of directors of non-ESB targets are outside directors. Because this difference is not statistically significant, we combine the two columns and find that boards of targets that remain independent are comprised overall of twothirds independent directors, hardly what would be characterized as a pathological board. These percentages persist when we examine only targets that remain independent in the long-run rather than the short-run. ${ }^{32}$ They are virtually the same as the percentage of outside directors on target boards that choose to sell. Most importantly, the percentages calculated here are almost exactly the same as the average percentage of outside directors on the boards of the S\&P 1500 companies, as recently calculated by the Investor Responsibility Research Center. ${ }^{33}$

We also examine majority-independence as a dichotomous variable to ensure that the averages in Figure 2 do not mask a bimodal distribution in board

32. ESB targets that remain independent thirty months after the bid is launched have boards that are $67 \%$ independent, on average, and non-ESB targets that remain independent have boards that are $63 \%$ independent, yielding an overall board measure of $65 \%$ independent. As with short-run target independence, the slight differences between ESB and non-ESB target board composition are not statistically significant.

33. See Investor Responsibility Research Ctr., BoArd Practices/BoArd Pay 2001: The Structure AND COMPEnsation of BoARds of Directors AT S\&P 1500 COMPANIES (2002) (finding, based on a slightly different definition of independence, that $65 \%$ of directors of S\&P 1500 companies are independent). This finding reflects a trend toward a higher percentage of independent directors that has been apparent since the early 1990s. See, e.g., Sanjai Bhagat \& Bernard Black, The Uncertain Relationship Between Board Composition and Firm Performance, 54 Bus. LAw. 921, 945 (1999) (reporting a decline in the number of inside directors at the median firm in their sample "due to changes since 1991 in the composition of a typical board"); Yermack, supra note 27, at 191 tbl.1 (finding 54\% outside directors, $10 \%$ gray directors, and 36\% inside directors among 452 of the largest 500 U.S. companies between 1984 and 1991). 
composition among our sample companies. We find that among the targets in our sample that remained independent, $78 \%$ had majority-independent boards. Among the targets in our sample that chose to sell, $84 \%$ had majorityindependent boards. This difference is not statistically significant $(\mathrm{z}$-statistic $=$ 0.82); moreover, both percentages are slightly (though not significantly) higher than the $75 \%$ of New York Stock Exchange companies that currently have majority-independent boards. Thus targets that remain independent in our sample do not seem to have boards that are significantly different, at least as judged by externally observable measures, when compared to the set of targets that choose to sell or the broader set of U.S. public companies.

Targets remaining independent not dominated by large-blockholder CEO. As a variant of his core argument, Gordon also speculates that target boards that do the wrong thing are dominated by the CEO: "In each of those [bad outcome] cases, the chairman and chief executive was a member of the founding family, held a substantial but noncontrolling stake, and had bitter personal and business rivalries with the suitors." 34 Again, Pennzoil provides an important counterexample to this claim: CEO James Pate owned $0.6 \%$ of the company, no other officer or director owned more than $1 \%$, and the only outside shareholder to hold more than $5 \%$ was a single institutional investor, which held $8.0 \%$. This case study evidence suggests, at the very least, that not all bad outcomes are the result of a dominant, large-block CEO shareholder.

As before, we test Gordon's claim more systematically by examining CEO ownership of all targets in our sample. In testing the hypothesis that high CEO ownership is correlated with a higher likelihood of remaining independent, we use two cut-offs: greater than 5\% CEO ownership; and greater than $10 \%$ ownership. Using the $5 \%$ cut-off, we find that $57 \%$ of targets in our sample with high CEO ownership remained independent, compared to $48 \%$ of targets with low CEO ownership. Using the $10 \%$ cut-off, we similarly find that $57 \%$ of targets with high CEO ownership remained independent compared to $47 \%$ of targets with low CEO ownership. While these results are at least directionally consistent with Gordon's hypothesis, neither difference is statistically significant (z-statistics $=-0.82$ and -0.64 , respectively).

Moreover, closer analysis of these results reveals that the difference is driven entirely by lower independence rates for targets with CEO ownership in the $2-5 \%$ range. Figure 3 shows target independence rate for various categories of CEO ownership: 
FIGURE 3: TARGET INDEPENDENCE RATE BY CEO OWNERSHIP

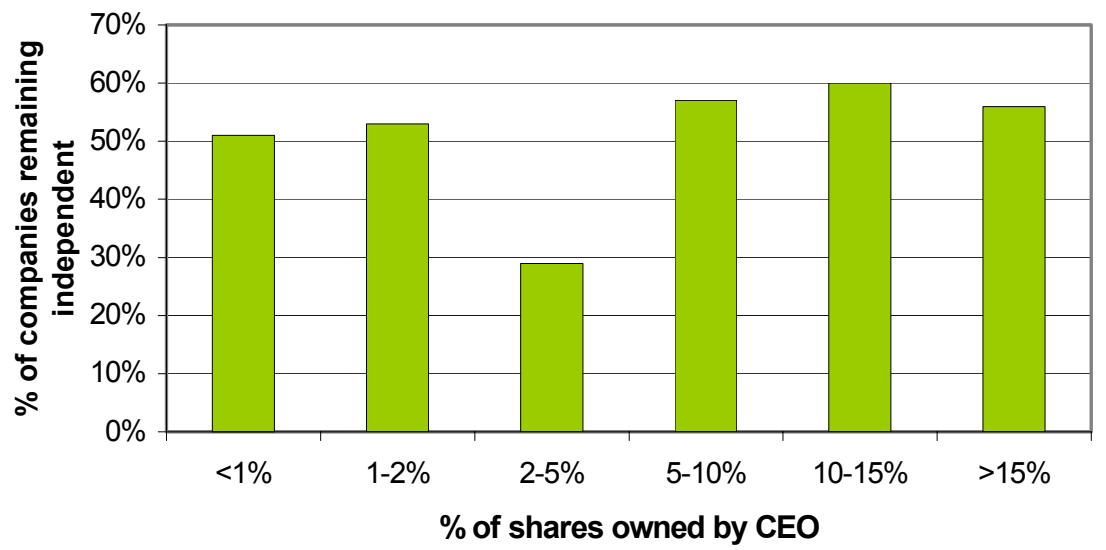

Figure 3 reveals that targets with CEOs who own between $2-5 \%$ of the company are substantially more likely to sell to either the hostile bidder or a white knight, at $95 \%$ confidence. This result continues to hold when we control for other factors that might influence bid outcomes, as reported in our original paper. No other levels of CEO ownership are statistically significant at $95 \%$ confidence. One potential explanation for this nonlinear result is that at low levels of CEO ownership the CEO does not have sufficient incentives to sell, while at high levels of CEO ownership the private benefits to the CEO are sufficiently large that the CEO is unwilling to sell. The latter result is consistent with prior work finding that the effectiveness of incentives declines for managers after certain levels of ownership. 35

While the $2-5 \%$ "sweet spot" is an interesting finding, it is inconsistent with Gordon's theory, which would predict that the target independence rate should be monotonically increasing in ownership - for example, $>5 \%$ CEO ownership should yield higher independence rates than $<2 \%$. Thus, neither the Pennzoil case study nor the aggregate evidence on CEO ownership is consistent with Gordon's conjecture that bid outcomes are the result of boards dominated by powerful CEOs.

\section{The Uneasy Case for Absolute Reliance on Independent Directors}

Bainbridge and Gordon both believe that shareholders would be best served by having a board with a majority of independent directors, who then

35. See Randall Morck, Andrei Shleifer \& Robert W. Vishny, Management Ownership and Market Valuation, 20 J. FIN. ECON. 293 (1988) (finding that the strength of correlation between ownership by the board of directors and market valuation first increases, then declines, and finally rises slightly as ownership rises). 
have full control over the decision whether to sell. ${ }^{36}$ Bainbridge argues that the maximization of shareholder wealth would be best achieved through "centralization of essentially nonreviewable decisionmaking authority in the board of directors." 37 Gordon similarly argues that we should rely on directors to "do the right thing" for shareholders, particularly when the board is composed of a majority of independent directors: "[I]f you trust directors to fulfill their duties, you want them to have the most powerful tools available." 38

The analysis in the prior section, however, demonstrates that having a majority of independent directors on the board provides us with no confidence that the board will do what is right for shareholders. Therefore, as an empirical matter, the reliance that Bainbridge and Gordon want to place on independent boards seems unwarranted. ${ }^{39}$ Moreover, it seems difficult to reconcile these views with recent events at Enron and elsewhere, in which outside directors were shockingly unaware of basic business issues that their companies faced. To rely so heavily on outside directors, who in general cannot be expected to devote large amounts of time to their director tasks, and who are dependent on officers for information, ${ }^{40}$ seems fundamentally flawed.

36. In fairness, none of our commentators had before them the evidence just reviewed, showing the lack of any clear relationship between board independence and bid outcomes. While it is possible that this new data might change their views on the wisdom of relying on independent directors, in this Part we assume for argument's sake that their views will not be swayed by this evidence.

37. Bainbridge, supra note 3, at 807. Bainbridge argues that without a board-centered view, a bidder would simply "mak[e] a low-ball tender offer to the shareholders, which they probably will accept due to the collective action problems that preclude meaningful shareholder resistance." $I d$. at 808. In fact, our proposal would provide an "undistorted choice" through the proxy contest route that would not fall prey to structurally coercive offers. See Lucian Arye Bebchuk, Toward Undistorted Choice and Equal Treatment in Corporate Takeovers, 98 HARV. L. REV. 1695, 1700 (1985) (defining the objective of undistorted choice as allowing takeover "if and only if a majority of the target shareholders view the acquisition price as higher than both the independent target's value and the value of other available offers"); see also Leo E. Strine, Jr., The Professorial Bear Hug: The ESB Proposal as a Conscious Effort to Make the Delaware Courts Confront the Basic "Just Say No" Question, 55 StAn. L. REV. 863, 877 (2002) (stating that "the threat of substantive coercion would seem to be at its nadir" when there has been an informed shareholder vote).

38. See Gordon, supra note 4 , at 830 .

39. Curiously, in a final footnote, Bainbridge seems to shift gears, abandoning his seemingly categorical reliance on boards and endorsing our policy proposal. See Bainbridge, supra note 3, at $818 \mathrm{n} .150$ ("It is hard to imagine situations in which it would be reasonable for a board to continue resisting an unsolicited offer after the hostile bidder has won an initial proxy contest."). If continued resistance fails reasonableness scrutiny, as Bainbridge suggests, then it would certainly fail the Unocal test that we propose should apply to this situation.

40. See, e.g., Jay W. Lorsch \& Elizabeth Maciver, Pawns or Potentates? The Reality of America's Corporate Boards (1989); Myles L. Mace, Directors: Myth AND ReAlity (1971); Laura Lin, The Effectiveness of Outside Directors as a Corporate Governance Mechanism: Theories and Evidence, 90 Nw. U. L. REV. 898, 913 (1996) (describing constraints on outside directors' ability to monitor). 
Yet Bainbridge and Gordon wish to go beyond the current state of the Delaware law and move toward exclusive reliance on boards in the takeover context. This view is inconsistent with the approach taken under current Delaware takeover law. While Delaware case law has given more weight to board decisions that are approved by independent, disinterested directors, Delaware law does not place this trust blindly, as Bainbridge and Gordon would have us do. Rather, Delaware carves out the takeover context as an area where we need to be concerned about "the omnipresent specter that a board may be acting primarily in its own interests." 41 For this reason the use of defensive tactics is reviewed using intermediate scrutiny under the well-known two-part test set out in Unocal.

\section{Implications for Current Corporate Governance Reforms}

It is worth noting that our findings also have implications for the recently enacted Sarbanes-Oxley Act of $2002^{42}$ and for the proposed revisions to the New York Stock Exchange (NYSE) listing standards. ${ }^{43}$ These reforms place heavy reliance on independent directors: Sarbanes-Oxley requires an entirely independent audit committee for every company listed on a national securities exchange, ${ }^{44}$ and the NYSE reforms further require a majority of independent directors overall and entirely independent compensation and nominating committees for NYSE-listed companies. But in the takeover context, we have seen that having independent directors hardly ensures that targets do not persist in just saying no, even when doing so results in shareholder losses. How does one explain this apparent lack of connection between board composition and bid outcome? What does this finding imply for the current reforms that seem to rely so heavily on independent directors to "do the right thing"?

Although a full analysis of these questions is beyond the scope of this Reply, we wish to make a few brief remarks. In recent work, one of us, with others, has analyzed two reasons as to why ostensibly independent directors might make choices in ways that are favorable to CEO's. ${ }^{45}$ First, even when directors are nominally independent, they are often influenced by the fact that the CEO was involved in getting them on the board; thus it is only natural that they are influenced in their exercise of discretion in favor of the person who

41. Unocal Corp. v. Mesa Petroleum Co., 493 A.2d 946, 954 (Del. 1985).

42. See Sarbanes-Oxley Act of 2002, Pub. L. No. 107-204, 116 Stat. 745.

43. See Corporate Governance Rule Proposals Reflecting Recommendations from the NYSE Corporate Accountability and Listing Standards Committee As Approved by the NYSE Board of Directors August 1, 2002 (No. SR-NYSE-2002-33 filed Aug. 16, 2002), available at $\mathrm{http}: / /$ www.nyse.com/pdfs/corp_gov_pro_b.pdf.

44. See Sarbanes-Oxley Act $\S 301$.

45. See Lucian Arye Bebchuk, Jesse M. Fried \& David I. Walker, Managerial Power and Rent Extraction in the Design of Executive Compensation, 69 U. CHI. L. REV. 751, 76474 (2002). 
gave them that opportunity. Second, independent directors often lack the independent information and the incentive to exert effort needed to enable them to take views opposite to the CEO. In the takeover context, for example, the investment banker is often chosen by management, and much of the valuation information that directors get comes from this investment banker. ${ }^{46}$ These explanations might provide some insight as to why independent directors do not provide a sufficiently adequate check on management, and, by extension, why the Sarbanes-Oxley Act and the revised NYSE listing guidelines may represent only modest and possibly insufficient steps to improve corporate governance more generally.

We wish to caution that we do not claim that independent directors are inherently ineffectual in making independent decisions on how to respond to a hostile bid, or more generally in making decisions. Such a blanket statement would be unwarranted for at least two reasons. First, the evidence from the late 1990s that we presented in our original paper may or may not predict how independent directors will act in response to the multitude of ongoing changes in law, markets, and business practices today-for example, increased public oversight of auditors, enhanced audit committee powers, CEO certifications of financial statements, high-profile prosecutions of prominent CEOs, etc. Second, how independent directors will act in any particular boardroom depends on a myriad of factors - for example, how they are selected, what independent sources of information they have, what incentives they have to monitor management, and so on.

Thus, we do not wish to make a prediction on how the new rules will influence how independent directors will act in general. All we claim here is that the presence of a majority of independent directors in the past has not reduced the likelihood of a harmful "just say no" defense in the context of a hostile bid. This finding leads us to be somewhat skeptical about relying exclusively on independent directors as the galvanizing force for corporate governance improvements in the future. Far better, it seems to us, to tilt slightly back toward a governance approach that balances shareholder and board power in the context of fully-financed, high-premium hostile takeover bids, at least absent explicit shareholder consent to the contrary. One way of doing so would be for courts to adopt the proposal that we describe in our original article.

\section{E. Other Objections}

Beyond the effects of independence and CEO ownership on board performance, Gordon raises several other issues in his commentary that we can address more briefly here. First, he argues that the "data set is stacked against

46. See, e.g., Brian J. Hall, Christopher Rose \& Guhan Subramanian, Circon (A) (Harvard Business School Case Study N9-801-403). 
ESBs" because ESBs receive a greater proportion of bear hug bids than nonESBs. ${ }^{47}$ Because bear hug bids are a weaker form of bid, it should be no surprise that they are successful less often than full bids. Our response to this point is twofold. First, as we report in our original paper, we in fact control for the potential effect of bear hugs in our multivariate regression models, for exactly the reasons that Gordon describes. 48 When we do so, we continue to find that ESBs have a substantial and statistically significant effect on target independence. Second, the decision to make a bear hug bid or a full bid is not exogenous to the target's takeover defenses: Bidders will be more inclined to make a bear hug bid against an ESB target precisely because the ESB defense is so potent. To use the driving analogy that Gordon has himself used in a separate critique of our work, 49 we do not need to observe several cars smashing into a wall to accept that the wall is sturdy. Accordingly, because bid tactics are endogenous to target defenses, we also run our multivariate regression model without the bear hug control, so that the effect of this endogeneity is (correctly) captured in the ESB coefficient. When we do so, we continue to obtain the result that ESBs are highly correlated with target independence. ${ }^{50}$

Similarly, Gordon questions whether the results we report are derived primarily from non-Delaware jurisdictions. "For all we know, the lower incidence of independence for ESB targets may have been concentrated in other jurisdictions with different legal features that help explain the results." 51 In fact, the results are even stronger when we examine only Delaware targets. Figure 4 shows short-run bid outcomes by target defenses, for ESB targets in Delaware $(n=29)$ and non-ESB targets in Delaware $(n=24)$.

47. Gordon, supra note 4 , at 827.

48. See Bebchuk et al., supra note 1, at 931 (describing results from a multivariate model which includes controls for bid features such as "proxy fight, bear hug bid, tender offer, [and] bust-up bid").

49. See Mark Gordon, Poor Study Habits, Daily Deal, June 20, 2002, at 16.

50. See Bebchuk et al., supra note 30 (presenting multivariate regression analysis results); Bebchuk et al., supra note 1, at 931 (reporting results from this and other tests).

51. See Gordon, supra note 4, at 828. 
Dec. 2002]

Figure 4: SHORT-Run BID OUTCOMES, DELAWARE TARGETS ONLY

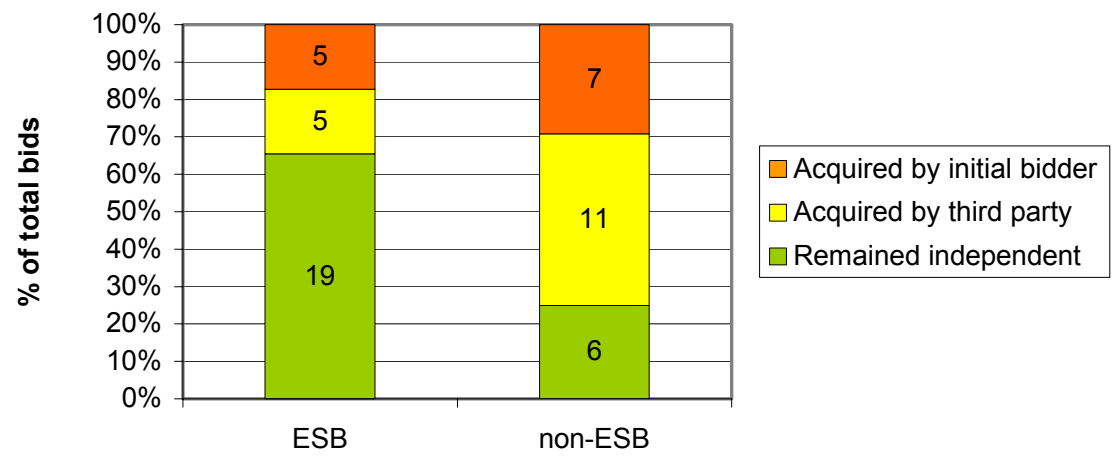

Figure 4 shows results for Delaware targets that are statistically indistinguishable from the outcome results that we report in our original paper.52 Therefore, our focus on the takeover law of Delaware seems warranted. Of course, even if the results in Figure 4 were not consistent with our overall results, the fact that most states look to Delaware for guidance on important issues of takeover law would seem to justify our focus.

Third, Gordon notes that our original study "fails to make any assessment of whether an ESB has a stronger antitakeover effect than an EAT." 53 In fact, in our follow-on paper we do include EAT as an independent variable but find that it has no statistically significant effect on bid outcomes. ${ }^{54}$ This finding highlights the unique potency of the ESB defense, and suggests that between the "delay problem" and "two-election problem" that we identify, the potency of the ESB might come primarily from the latter.

Finally, Gordon argues that our calculation of the effects of remaining independent ignores the harmful effect of the hostile bid itself. 55 This assertion is incorrect. If hostile bids harm targets, then targets that sell should also produce lower returns than if no bid had been made. What we are measuring in our analysis is the difference between returns to targets that remain independent and returns to targets that sell. Because all of the targets in our sample have received a hostile bid, the negative effect that Gordon describes will cancel out in our calculation. 56

52. See Bebchuk et al., supra note 1, at 930 fig.3.

53. See Gordon, supra note 4 , at 827.

54. See Bebchuk et al., supra note 30 .

55. See Gordon, supra note 4 , at 825 .

56. Gordon claims that we "have not made available, and this author has not had access to," the data underlying the study. See id. at 823 n.17. In fact, all of the data on which we rely is publicly available, and we have described in detail our data sources in our original article. See Bebchuk et al., supra note 1, at 925-26. Therefore, our raw data is available to 


\section{COUNTERVAILING BENEFITS IN FRIENDLY ACQUISITIONS}

Our analysis thus far has focused on extending and refining the core model that we presented in our original paper. In this core model we focused on the set of hostile bids since 1996, currently 112 in number. ${ }^{57}$ We have documented the outcomes of these bids in both the short run and in the long run, and have attempted to estimate the wealth effects of the various outcomes. This approach follows closely from the existing, well-developed literature on the market for corporate control, and allows us to focus squarely on the issues that confront the Delaware courts. We have sought to contribute in this way, and we are glad that some of the participants in this Symposium accept the picture that we have put forward in this respect.

However, Gordon and Bainbridge argue that ESBs can have potentially beneficial effects in the form of higher premiums for targets in negotiated transactions. ${ }^{58}$ In this Part we present the first empirical evidence on this question, and find that it does not support the Gordon/Bainbridge hypothesis. We also refute the anecdotal, case-study evidence that Gordon presents in support of this view. Combining the finding presented in this Part with our earlier findings, we believe that the burden must be on takeover defense proponents to present evidence in support of their view.

\section{A. Do ESBs Necessarily Increase Premiums in Friendly Negotiations?}

Gordon assumes that ESBs must have a positive impact on premiums in negotiated acquisitions. The more powerful the weapons on the part of incumbents to stop a hostile bid, goes the argument, the more bargaining power the incumbents must have. Because it would be "an impossible feat of logic" to argue otherwise, Gordon claims that we concede that ESBs give targets bargaining power and thereby lead to increased premiums in friendly transactions. ${ }^{59}$ In fact, we make no such concession-rather, we view the question as very much an open one. ${ }^{60}$

Gordon and others.

57. While we could in theory go back to earlier bids, one of us in other work argues and presents evidence that the just say no defense only became truly solid in Delaware in the mid-1990s. See Guhan Subramanian, The Disappearing Delaware Effect (Harvard Law School Olin Paper 391, November 2002). If the early 1990s were in fact a different takeover era, then the bids from this era would not be directly comparable to the bids in our sample. Of course, one could make the same argument for hostile takeover bids going forward - that the recent scandals and reforms in corporate governance have led us to a still different takeover marketplace than the one we analyze in our paper. To this point we can only say, "Too soon to tell."

58. See Bainbridge, supra note 3 , at 808 ; Gordon, supra note 4 , at 823 .

59. Gordon, supra note 4, at 823-24.

60. See Bebchuk et al., supra note 1, at 936 (" [T] he evidence is not sufficient even to conclude that there is any positive effect at all of ESBs on deal premiums, though we cannot reject this possibility with our small-sample analysis."). 
Dec. 2002]

Indeed, in recent work, one of us discusses in detail whether theory clearly predicts that board veto would produce higher premiums compared with a regime such as the one we propose, and concludes that it does not. ${ }^{61}$ First, under the approach we recommend, incumbents would hardly lose the ability to bargain for shareholders. Incumbents would still be able to delay an acquisition until a shareholder vote takes place, and, conversely, consent by incumbents would enable a much faster resolution, even assuming that shareholders would ultimately favor the offer. Furthermore, incumbents' support would presumably increase the likelihood of shareholder approval. Note that lawyers can and do bargain on behalf of their clients, for example, even though they generally have no veto power because the client can accept a settlement offer at any time.

Thus, giving boards veto power over takeover bids is not needed to enable significant bargaining by boards on shareholders' behalf for a long period of time, provided only that shareholders are content to have management continue bargaining and do not intervene to take management's bargaining mandate away. Furthermore, whatever extra bargaining leverage management might obtain from board veto power might be used not to extract a higher premium, but rather to obtain a better treatment for management. In fact, recent empirical evidence indicates that managers are willing to accept lower premiums for shareholders in acquisitions providing more favorable treatment of managers. ${ }^{62}$

With theory not enabling a clear prediction on the effect on friendly deal premiums, the question is, therefore, whether there is any evidence that the alleged effect exists and is substantial. Neither Gordon nor Bainbridge provides or cites any evidence that this is the case. In fact, such evidence does not exist, and new preliminary evidence that we have gathered fails to unearth such an effect.

\section{B. The Poison Pill "Evidence"}

In a prior critique of our work, ${ }^{63}$ and to some extent in his response here, ${ }^{64}$ Gordon has pointed to the poison pill studies as evidence in favor of the higher

61. See Lucian Arye Bebchuk, The Case Against Board Veto in Corporate Takeovers, 69 U. CHI. L. REV. 973, pt. II.C.4 (2002).

62. See Jay Hartzell, Eli Ofek \& David Yermack, What's in It for Me?: Personal Benefits Obtained by CEOs Whose Firms Are Acquired (March 2000) (unpublished manuscript, on file with authors); Julie Wulf, Do CEOs in Mergers Trade Power for Premium? Evidence from "Mergers of Equals" (June 2002) (unpublished manuscript, on file with authors) (reporting findings suggesting that CEOs trade power for premiums by negotiating shared control in the merger firm in exchange for lower shareholder premiums).

63. See Gordon, supra note 49 (citing the pill studies and their conclusion "that companies that have these [poison pill] plans receive higher takeover premiums than those that do not have them").

64. See Gordon, supra note 4 , at $824-25$ (citing the pill studies again but also acknowledging the critique of these studies that one of us has provided elsewhere). 
premiums hypothesis. These studies consistently find that targets with poison pills received higher premiums than targets without pills. However, these studies are flawed in two important ways. First, accepting for a moment their results at face value, the pill studies cannot distinguish between a story in which defenses allow target boards to extract higher premiums and a story in which low-premium bids are simply deterred by the pill. The two stories are observationally equivalent in the studies to date, yet lead to very different implications for the net effect of pills on shareholder value. Second, virtually all companies have "shadow pills" that can be put in to place after a hostile bid has been launched. 65 One of us has demonstrated in prior work that that these shadow pills make the results of pill premium studies difficult to interpret at best, and perhaps meaningless. ${ }^{66}$ Thus the pill studies provide no useful evidence on the validity of the higher premiums hypothesis.

\section{New Evidence on the Higher Premiums Hypothesis}

Studies of the ESB defense would not necessarily suffer from these same flaws, but despite twenty years of research on takeover defenses, such studies have not been done. This omission is particularly puzzling to us because the higher premiums hypothesis seems to be central to the argument for "new school" takeover defense proponents such as Gordon and Bainbridge. In our original study of hostile bids, we found no evidence that managers of ESB targets were able to achieve higher premiums for their shareholders than managers of non-ESB targets. ${ }^{67}$ Here, we accept Gordon's challenge to expand our scope and examine a sample of friendly deals as well.

Our sample includes all mergers or acquisitions of public company targets that are included in the sharkrepellent.net database, from the inception of that database in October 2000 to June 2002.68 Our sample includes 39 ESB targets and 34 non-ESB targets - admittedly a small sample, but a first step towards an empirically rigorous assessment of the higher premiums hypothesis. The premiums in these 73 deals, calculated relative to the announcement date for the deal and classified by the target's defenses, are given in Figure 5:

65. See John C. Coates IV, Takeover Defenses in the Shadow of the Pill: A Critique of the Scientific Evidence, 79 TEX. L. REV. 271, 286-91 (2000).

66. Id. at 311-14.

67. See Bebchuk et al., supra note 1, at 935-36.

68. This sample includes the Willamette-Weyerhaeuser deal, which we describe in more detail infra Part II.D. 


\section{Figure 5: MEdian Bid PREMIUM by TARget DeFENSES}

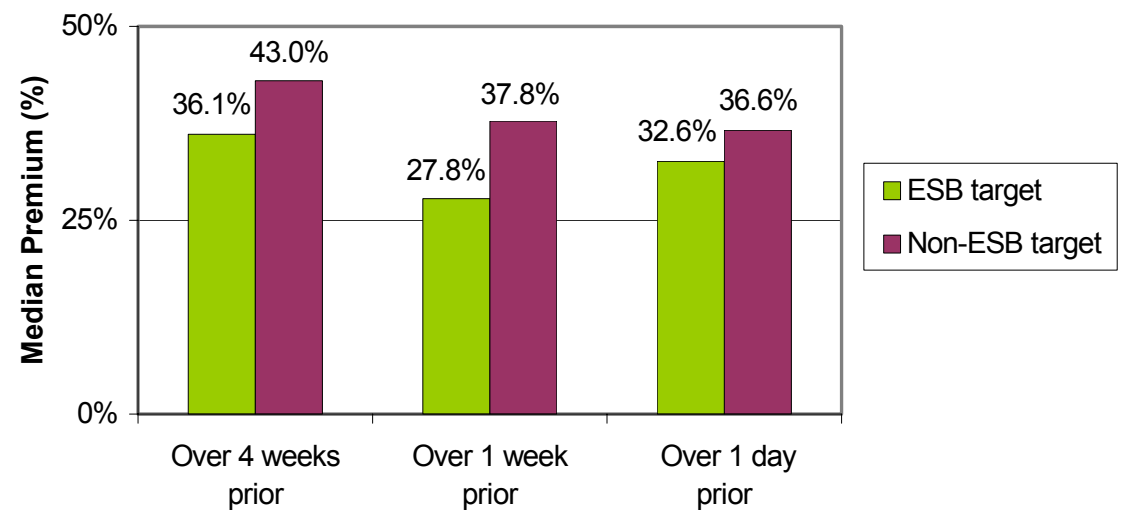

Figure 5 shows only slight differences between premiums for ESB and non-ESB targets - in fact, sample medians are lower for ESB targets, contrary to what the higher premiums hypothesis would predict, though these differences are not statistically significant. These (non) results continue to hold when we control for other factors such as financial performance of the target (sales growth, Tobin's Q, and return on assets), size of target (log of net sales), and industry. 69

To be sure, because of the small size of the sample studied, more work on a larger sample would be needed to reach confident conclusions. Until such work is done, however, the preliminary evidence that we present appears to be inconsistent with the bargaining hypothesis. ${ }^{70}$

We conclude by turning to the anecdotal evidence that takeover defense proponents use to support their view. At the outset, we note that even an ideal anecdote in which a higher premium was paid after the target initially resisted should convince no one that the ESB produced the higher premium. The reason is simple: For every ESB target in our sample that resisted the hostile bid and finally sold for a higher price, there is a non-ESB target that achieved equal or better gains for its shareholders. First offers are just that-first offers - and just as it would be surprising for someone to accept the first offer from a used car dealer, it would be surprising for any target, ESB or otherwise,

69. Of these variables, the only one that was statistically significant in a consistent way was net sales, which was negatively correlated with premium.

70. Moreover, the potential for bid deterrence against ESB targets would only serve to reduce the likelihood that ESBs create value for shareholders overall. Or, put differently, even if we were to find from the simplistic analysis presented in Figure 5 that premiums were in fact higher against ESB targets, we could not conclude from this evidence alone that ESBs were value-enhancing. 
to agree to a bidder's first offer. Weyerhaeuser's hostile bid for Willamette illustrates the danger of resorting to anecdote with respect to the higher premiums hypothesis. We nevertheless turn to this case study now.

\section{Case Study: Weyerhaeuser's Hostile Bid for Willamette}

In a recent exchange with one of us, Martin Lipton used the January 2002 takeover of Willamette as an example of a hostile bid for a target with an ESB in which the presence of an ESB benefited shareholders. ${ }^{71}$ As part of that exchange, one of us has provided a detailed analysis of the Willamette takeover saga. This analysis suggested that the stalling by incumbents, aided by a staggered board, did not provide Willamette's shareholders with any significant benefit. ${ }^{72}$

Gordon takes issues with this Willamette analysis. To briefly recap the Willamette bid: Willamette received a bid of $\$ 48$ per share from Weyerhaeuser in November 2000, and its board finally capitulated to shareholder pressure and agreed to be acquired for $\$ 55.50$ per share in January 2002 . Gordon argues that, although the stalling produced only an increase of $16 \%$ from the initial bid, the $16 \%$ stands favorably when compared with the performance of the general stock market and Willamette's industry between November 2000 and January 2002. But this analysis misses a key point: There is little reason to believe that a $16 \%$ increase from the initial bid required stalling and refusing to engage in any negotiations for many months.

Bidders are generally willing to offer somewhat more than the initial bid to get the deal done, and there are aspects of the Willamette story which lead one to believe that an increase could have been obtained in this case even without massive stalling. ${ }^{73}$ In fact, when Weyerhaeuser made its bid in November 2000 , an analyst guessed that "the two companies will go to the bargaining table by the end of next week and reach a deal at $\$ 55$ a share, possibly a tad higher."74 But despite the strong signals that investors wanted to have discussions with the hostile bidder, Willamette's incumbents kept refusing to enter such discussions, saying that Willamette "is not for sale." 75 This refusal persisted after Weyerhaeuser stated explicitly in May 2001 that it would raise its offer if Willamette would negotiate a friendly deal; Willamette did not enter into discussions to even explore what increase in premium Weyerhaeuser

71. See Martin Lipton, Pills, Polls, and Professors Redux, 69 U. CHI. L. REV. 1037, 1057 (2002).

72. See Bebchuk, supra note 61 , at 1030-33.

73. For a fuller account of the facts noted below, see $i d$.

74. Nikhil Deogun, Weyerhaeuser Plans to Make Hostile Bid of $\$ 5.4$ Billion for Willamette Industries, WALl ST. J., Nov. 29, 2000, at A4 (quoting Mark Wilde, an analyst at Deutsche Banc Alex. Brown).

75. See Willamette Rejects $\$ 5.5$ Billion Offer From Weyerhaeuser, WaLl ST. J., May 10, 2001, at C18. 
would be willing to offer. Only in October 2001, eleven months after the initial bid, and two months after being defeated in a proxy contest that enabled Weyerhaeuser to replace one-third of the board, did Willamette express willingness to sit down with Weyerhaeuser to explore how much it would be willing to raise its bid. If bargaining for a higher price was the goal of the board, why did the board for eleven months not even explore with Weyerhaeuser whether it would be willing to raise its price by at least $15 \%$ in order to get the deal done? ${ }^{76}$

In short, the Willamette case, which Lipton described as a "shining example" for successful bargaining facilitated by an ESB, 77 and which Gordon similarly views as very supportive, is hardly favorable to ESBs. We hope that future research will provide more evidence on this question. In the meantime, however, there is no basis for viewing the effect on premiums in negotiated acquisitions as sufficiently favorable to outweigh the clearly undesirable effect it has for hostile bids.

\section{OUR PROPOSED APPROACH}

\section{A. Rules vs. Standards}

In our original article we suggested that courts should carefully scrutinize the maintenance of a pill after the incumbents have lost a first election, and should generally require incumbents to redeem the pill in this situation. Both Vice Chancellor Strine and Professor Bainbridge raise questions about our formulation of a rule-like arrangement. They correctly observe that such a rule would not be in the spirit of how Delaware courts approach things. Vice Chancellor Strine, for example, characterizes our proposal as a "bright-line" approach that avoids the case-specific factfinding that Unocal has been thought to require, but also loses the benefits of the "muddling through" that characterizes the common law. ${ }^{78}$ Bainbridge praises Delaware courts for

76. Gordon also allows that Willamette might have been a pathological case of bad corporate governance. Gordon, supra note 4, at 835. In this respect, he differs from Lipton, who views the Willamette board as a "shining example" of a board acting in its shareholders' interests. Lipton, supra note 71, at 1057. Gordon seems to admit that Willamette's board might have displayed an intransigence that "somehow went well beyond mere bargaining strategy"- but cautions against drawing conclusions from this because "Willamette is a 'hard case' because it provides an example of a board for which the independence model had been significantly warped by a history of tremendous personal animosity and business rivalry between the raider and the target." Gordon, supra note 4, at 834 n.70, 835. For more systematic evidence on this point, see supra Part I.B.2.

77. Lipton, supra note 71 , at 1057.

78. Strine, supra note 37 , at 881 . 
having "remained faithful to their preference for the Unocal standard of review over the many prophylactic rules advocated by academics."79

On reflection, we concede that our approach would be better cast in the language of a standard. Thus, in our view, courts should give much weight in deciding whether a pill should be maintained to whether or not there has been a shareholder vote. If such a vote has been cast and lost, we continue to believe there should be a strong judicial presumption that maintaining the pill would be disproportionate or preclusive. But even under our (now-clarified) proposal, the target board should have an opportunity to persuade a court that its reasons for maintaining a pill were justified by unusual facts or circumstances.

We make this concession not simply to make our approach more palatable to some observers. Rather, on reflection, we too can readily envision situations - which we nevertheless believe would be unusual-in which it would make sense for a judge to decline to order an immediate redemption of a pill following the defeat of incumbents in an election. Suppose that incumbents were defeated in such an election but that the following day a new potential buyer emerged and offered to negotiate with management an acquisition at a much higher premium. Or suppose it was discovered that the bidder had been clearly and flagrantly engaging in insider trading to support its bid, or had been intentionally misleading the marketplace about its bid financing (in a cash bid) or future prospects (in a bid involving stock consideration).

In such plausible but unusual instances, it would be reasonable for a court to retain the discretion to allow a target to maintain a pill, either to provide the target time to negotiate with a new bidder or for the market to digest and target shareholders to respond to new information. Indeed, we can even imagine situations where a court would allow a target to maintain a pill in place until (yet another) election were able to be held that would allow shareholders to vote with full information, although we would caution against allowing targets to request such judicial forbearance for any reason other than truly significant developments. Presumably, it would be more difficult for a legislature to anticipate and accommodate all of the potential exceptions within a general pronouncement on defenses. For these reasons, we agree that our proposal is best implemented as a court-enforced standard rather than a bright-line rule. 80

79. Bainbridge, supra note 3 , at 814 .

80. We note that although legislation is generally "rule-like" and judicially developed common law is generally "standard-like," this need not be the case. See Louis Kaplow, Rules Versus Standards: An Economic Analysis, 42 DuKe L.J. 557, 588-90 (1992). Thus, our agreement here that standards should continue to prevail in the takeover arena is not inconsistent with Vice Chancellor Strine's call for legislative guidance, which we would endorse. Strine, supra note 37, Part IV. 


\section{B. Judicial Moderation}

In his essay, Vice Chancellor Strine explains the difficult role that the Delaware courts face in developing takeover doctrine in the absence of clear legislative directive. He views our proposal as seeking the Delaware judiciary to "fill the legislative vacuum, by taking bold and decisive judicial action." 81 This raises the question of whether, whatever might be the substantive merits of our approach, following it would be a departure from the "cautious, evolutionary approach" which the Delaware judiciary understandably seeks to follow. 82

We would indeed welcome intervention by the Delaware legislature to chart an optimal allocation of power between shareholders and directors in the takeover context. Indeed, in our original article, we discussed what would be the optimal menu of takeover defenses that a legislature might want to provide. ${ }^{83} \mathrm{We}$ are, however, realists. Legislative intervention appears unlikely in the foreseeable future. The last time the Delaware legislature acted in this area was 1988, when it adopted a moderate antitakeover statute. ${ }^{84}$ This statute was adopted three years after the Unocal, Moran, and Revlon decisions provided a basis for judge-made law on takeover defenses, and the legislature clearly, if implicitly, opted to leave the sensitive matter of takeover defenses to subsequent development of case law. Given that pressures for legislative intervention are probably weaker today than they were in the late $1980 \mathrm{~s}$ and early 1990s, we have little reason to expect legislative action on takeovers anytime soon.

Given this background, we believe that our approach in fact represents a path for the Delaware courts to develop that is more consistent with a moderate, cautious, and evolutionary judicial role than are plausible alternatives. To start with, the last time the Delaware legislature acted, it chose to move neither in the direction of preventing takeover defenses (as the SEC and many institutional shareholders and academics advocated), nor in the direction of providing incumbents with the power to veto acquisitions (as some other states did). ${ }^{85}$ In our view, our approach provides the least intrusive yet principled way to prevent Delaware courts from falling into complete deference to board veto. ${ }^{86}$

Moreover, we would stress that it was not solely the courts, but the Delaware legislature that-in enacting the compromise on Delaware General

81. Strine, supra note 37 , at 882 .

82. Id. at 881 .

83. See Bebchuk et al., supra note 1, at 948-50.

84. See Del. Code ANN. tit. 8, § 203 (2001).

85. E.g., 15 PA. Cons. StAT. AnN. § 1715(a) (West 2002).

86. $C f$. Strine, supra note 37 , at 879 n.45 (likening Bainbridge's alternative to "the business judgment rule standard's 'rationality' test," with the practically complete deference to well-advised boards that it implies). 
Corporation Law section 203 in 1988 - chose to leave in place the approach established by the Delaware judiciary. Under this approach, courts would allow directors to maintain a pill only on conditions of (1) judicial review for proportionality under Unocal and (2) the "proxy out," as Vice Chancellor Strine succinctly summarizes the express linkage in Moran between the pill's legitimacy and the importance of an effective shareholder voting mechanism. As we discussed in detail in our original article, our approach can be viewed as the most reasonable implementation of these principles. Allowing incumbents generally to maintain a pill after losing one election conducted over a fully financed offer would gut Unocal and effectively eliminate the "proxy out." By keeping the original promise of Moran, our proposal would not be a departure from the cautious evolutionary chart but rather its most sure continuation. ${ }^{87}$

Another way of seeing why following our approach would be more expressive of judicial moderation than general judicial endorsement of just say no is to reflect on the courts' role in the legitimation of the poison pill itself. As Vice Chancellor Strine noted on another occasion, ${ }^{88}$ the Delaware General Corporation Law provides (as a default matter) no restrictions on the freedom of shareholders of a public corporation to sell their shares. Yet the ability of incumbents to impede hostile bids has largely resulted from the evolution of a judge-made body of law that permits incumbents to use pills-devices created precisely to prevent shareholders from selling their shares to a willing bidder. Only by conditioning judicial approval of pills on both a substantive form of proportionality review and on the "proxy out" can the developments be plausibly reconciled with the absence of default transfer restrictions in the Delaware statute. Thus, by moving quite far in the direction of allowing incumbents to block offers, but declining to move so far that bid-blocking could be done without proportionality review and the "proxy out," the Delaware courts have "forged a compromise." 89 To now drop the requirements of proportionality review and the "proxy out" would be a much more radical change in Delaware jurisprudence than sticking with the compromise and upholding the original terms of Moran.

\section{The Extreme Positions of Our Critics}

The converse of the points just made are also important to keep in mind. While our approach would be consistent with judicial moderation and established principles, the approaches supported by our critics represent startling and radical departures from both Delaware tradition and common

87. Cf. Bainbridge, supra note 3, at 797 n.34 (stating that we "propose adding yet another standard of review to Delaware law").

88. See Leo E. Strine, Jr., Categorical Confusion: Deal Protection Measures in Stockfor-Stock Merger Agreements, 56 BUS. LAW. 919, 925 (2001).

89. Strine, supra note 37 , at 871. 
sense. Gordon, Bainbridge, and Stout all wish practically to give directors unfettered and indefinite power to block bids. ${ }^{90}$

This position would be a clear departure from well-established doctrinal principles in Delaware. As Vice Chancellor Strine describes, the Delaware courts have clearly chosen to apply a different standard from the business judgment rule to defensive tactics. The Unocal standard establishes limits on the use of the most potent of these weapons. This is done because of the recognition that the takeover context is one in which courts must recognize the "omnipresent specter" of a board acting in its interest. The level of deference that Gordon, Bainbridge, and Stout wish to give to directors is one that Delaware law has long ago decided to reject.

It is also worth noting that the position of these three critics represents a rather extreme area in the continuum of legal attitudes toward defensive tactics. As reflected in Figure 6, this continuum runs between one extreme, in which incumbents would not be allowed to engage in any defensive tactics (as advocated by Judge Easterbrook and Dean Fischel in 1982,91 and as effectively implemented by the British City Code ${ }^{92}$ ) to another extreme, in which incumbents should be able to "just say no" indefinitely under the protection of the business judgment rule (as advocated by Martin Lipton in 197993 and as effectively implemented in the Netherlands ${ }^{94}$ ).

90. See Bainbridge, supra note 3, at 816-18; Gordon, supra note 4, at 830 ("The decision [whether to 'just say no'] remains in the hands of duty-bound directors. And if you trust directors to fulfill their duties, you want them to have the most powerful tools available."); Stout, supra note 2, at 848-49.

91. See Frank H. Easterbrook \& Daniel R. Fischel, The Proper Role of a Target's Management in Responding to a Tender Offer, 94 HARV. L. REV. 1161, 1164 (1981).

92. See City Code on Takeovers \& Mergers, General Principles, in 2 WeInBerg \& BLANK ON TAKE-OVERS AND MERgERS 7001 (Laurence Rabinowitz ed., 5th ed. 1989); Paul L. Davies, Gower's Principles OF MODERn COMPANY LAW 783 (6th ed. 1997) (“After a bona fide offer... no action may be taken by the board without the approval of [shareholders] which could result in the offer being frustrated ...."). The United Kingdom imposes some delay on a bid, to allow target shareholders time to consider the bidder's proposal, and effectively requires equal treatment of target shareholders. See TAKEOVER Panel, City Code on TAKeOvers and Mergers Rules 31, 34 (7th ed. 1992). In contrast, the Easterbrook \& Fischel proposal would have permitted "Saturday Night Specials"virtually overnight takeovers - without delay.

93. See Lipton, supra note 5.

94. For a description of the laws regulating takeovers of companies in the Netherlands, see SteVen R. Schuit \& JAN-ERIK JANSSEN, M\&A IN THE Netherlands 113-35 (1996) (“To date, no hostile offer has been successful in the Netherlands."); Abe de Jong, Douglas V. DeJong, Gerard Mertens \& Charles E. Wasley, The Role of Self-Regulation in Corporate Governance: Evidence from the Netherlands (Oct. 30, 2001) (unpublished manuscript), available at $\mathrm{http}: / /$ papers.ssrn.com/sol3/papers.cfm?abstract_id=246952. 


\section{Figure 6: CONTINUUM OF VIEWS ON TAKEOVER DEFENSES}

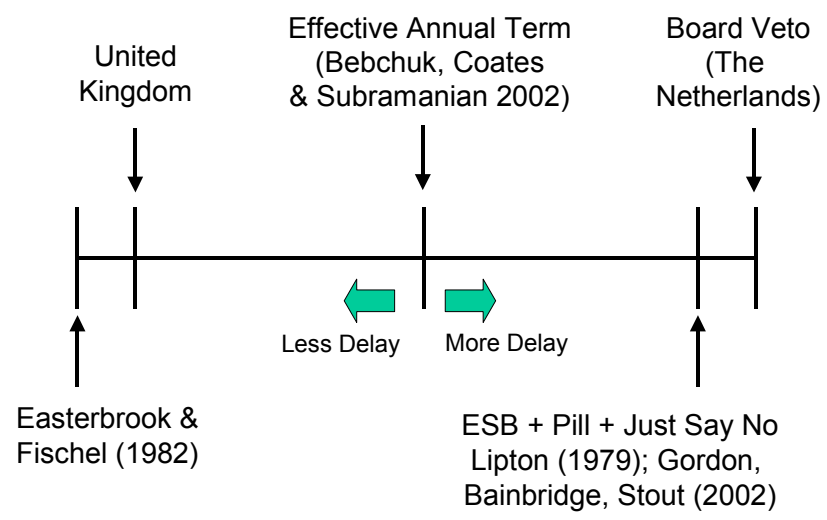

Adoption of our approach would still leave incumbents with substantial power to block offers for a significant period of time (converting the ESB-pill combination into an effective annual term or EAT) between the commencement of a bid and the election of target directors in the context of that bid. Moreover, if our proposal were implemented as a standard, rather than a hard-and-fast rule, courts could even allow target boards some time after a first election loss, as long as the justifications for so doing were compelling.

But our three critics wish to go nearly to the end of the continuum. Admittedly, they would not give target boards outright discretionary blocking power that could last indefinitely, as does the Netherlands. But, as the data in our original article demonstrate, allowing target boards to sit behind an ESBpill combination, subject only to the procedural requirements of good faith and information of the business judgment rule standard and the theoretical ability of bidders to last through two proxy fights, is much closer to the Netherlands end of the spectrum than it is to any practically available moderate position. Seen in this context, our critics' position is in fact quite radical. ${ }^{95}$

95. We omit from our spectrum the proposal put forward by Lipton and Rosenblum proposing a quinquennial election of directors, see Martin Lipton \& Steven A. Rosenblum, $A$ New System of Corporate Governance: The Quinquennial Election of Directors, 58 U. CHI. L. REV. 187, 224-25 (1991) (proposing election of directors every five years), because it is not clear at the level of theory whether this proposal would fall to the left or right of the "ESB+Pill+Just Say No" position in Figure 6. On one hand, the quinquennial election of directors does not suffer from the "two-election problem" that we suggest here might be more important than the "delay problem" in making the ESB defense so potent. See supra text accompanying notes 53-54. Similarly, the minimum delay in the Lipton \& Rosenblum regime is shorter than the minimum delay against an ESB. Cf. Bebchuk et al., supra note 1, at 918 tbl.1. Both of these factors suggest that the regime proposed by Lipton \& Rosenblum might be less entrenching than an ESB. On the other hand, the maximum delay under the Lipton \& Rosenblum regime would be five years, far greater than against an ESB. The net 
Why go that far? Our critics are unable to deny that ESB-pill combinations have the adverse effects we identified. What they do is speculate about other potential effects that might point in beneficial directions - in particular, effects on negotiated premiums (Gordon, Bainbridge) or ex ante investments by stakeholders (Stout). They provide no evidence beyond the realm of anecdote that these beneficial effects exist or what their magnitude is. ${ }^{96}$ Instead, they attempt to place the burden of proof on the moderates in this debate - on the Delaware courts and on us. Their policy argument thus boils down to this: As long as no one can demonstrate that the conjectured beneficial effects of the ESB-pill combinations do not exist, directors should be given unlimited power to say no. The rationale for such a strong presumption in favor of such a radical position is never made clear.

What should be clear is that the takeover policy choices that have been debated for over half a century are ones that neither deductive theory nor plausibly testable evidence can be expected to resolve in a way that is compelling and demonstrably indisputable to those who are inclined to disagree, at least any time in the near future. When faced with such intrinsically debatable issues, lawmakers have no choice but to form a

effect relative to an ESB regime would no doubt be context-specific and is difficult to represent on our one-dimensional spectrum. For similar reasons we also do not place the Allen, Jacobs, and Strine proposal for triennial election of directors on our spectrum, see William T. Allen, Jack B. Jacobs \& Leo E. Strine, Jr., The Great Takeover Debate: A Meditation on Bridging the Conceptual Divide, 69 U. CHI. L. REV. 1067, 1097 (2002) (proposing election of directors every three years), but we point out in our original article that there are good reasons to believe that such a regime would be less entrenching than the ESB regime, and therefore closer to our own EAT proposal. See Bebchuk et al., supra note 1 , at 918-19.

96. Several commentators point to evidence previously presented by one of us. See John C. Coates IV, Explaining Variation in Takeover Defenses: Blame the Lawyers, 89 CAL. L. REV. 1301 (2001) (showing a large and increasing number of firms adopt defenses prior to IPOs). But what one can at most conclude from that evidence is that "defenses are optimal for pre-IPO shareholders to adopt at a large subset ... of new firms" and that "it is more plausible that such defenses are optimal for all firms than it is that they are optimal for none." Id. at 1385. Furthermore, whatever inferences one might wish to draw from IPO decisions during the 1990s have to be balanced against inferences that could be drawn from shareholders' consistent voting during this decade against antitakeover charter provisions and from IPO decisions during the preceding decade. See Bebchuk, supra note 62, at 101619.

Two additional reasons why IPO decisions during the 1990s do not undermine our proposed approach were identified in our earlier article: (1) firms that went public with ESBs represent only a small fraction of firms overall, and (2) firms that went public in the 1990 s, after the development of the pill and just say no, are an even smaller fraction of firms overall. See Bebchuk et al., supra note 1, at 939-50. In addition, we note that-beyond concerns one might have about whether IPO markets adequately "price" defenses, and thus how informed or real any implicit consent given to pre-IPO defenses by IPO investors wastwo factors undermine the idea that IPO investors in the 1990s knew firms with ESBs would be as invulnerable to bids as our original article shows: (1) legal uncertainty over just say no persists, even today, and (2) even sophisticated legal practitioners greatly underestimated the effect of ESBs on bid outcomes prior to the publication of our article. See id. at 901-02. 
judgment informed as best as possible by available theory and evidence. Moreover, where absolute proof in matters as the one under debate is unattainable, and judgment is required, issues of legitimacy and continuity with tradition matter more than they might otherwise.

On tradition, as we have argued here and in our original article, we believe that the ESB-pill-"just-say-no" combination is simply inconsistent with Delaware's existing jurisprudence and the implicit sanction to that jurisprudence given by the Delaware legislature in 1988. On legitimacy, our original article documented that the great majority of ESBs were adopted by companies prior to the legal developments that made them such a powerful device when combined with a pill. And, as we noted and Patrick McGurn forcefully describes in this Symposium, ${ }^{97}$ most informed shareholders of U.S. public corporations, who never consented to have their companies governed by such antitakeover protections, would commonly favor some limitation on the abuse of ESBs.

In recent work reviewing the full range of effects of board veto and the evidence available regarding them, one of us has expressed a confident judgment that a board veto is overall highly likely to be undesirable as a policy matter. 98 Others among us are somewhat more agnostic about this more general policy question. ${ }^{99}$ All three of us believe, however, that the best currently available theory and evidence, coupled with additional considerations discussed in our original article and briefly above, make allowing directors to maintain a pill following electoral defeat the wrong way to go for Delaware courts, at least in the absence of explicit and informed shareholder approval to the contrary.

\section{CONCLUSION}

We began our project on the antitakeover power of effective staggered boards more than three years ago, in a different era of corporate governance

97. See Patrick S. McGurn, Classification Cancels Corporate Accountability, 55 STAN. L. REV. 839 (2002).

98. See Bebchuk, supra note 61, at 1012 .

99. At least one of us believes that the question remains more uncertain, for reasons discussed in the text, and because he is at least open-minded about the possibility that either Bainbridge or Stout is right-either that takeover threats can harm shareholders ex ante, or that ex ante investments by executives or other key constituencies would be encouraged if takeovers were nearly impossible, and that board power to block takeovers is at least a second-best way to encourage such investments. But the evidence on both points remains sufficiently controversial — see, for example, RONALD J. GILSON \& BERNARD S. BLACK, THE LAW AND FINANCE OF CORPORATE ACQUISITIONS 619-34 (2d ed. 1995), for a critique of the evidence in Shleifer \& Summers, cited by Stout, supra note 2, at $850 \mathrm{n}$.16- that any fair reading of the evidence would leave one uncertain at best, at which point concerns regarding tradition and legitimacy become dispositive on the precise policy question our article raises: Whether a board should be able to use an ESB-pill combination to block a bid after losing an election, absent explicit, clear, and informed shareholder authorization to do just that. 
from the one we live in today. The recent events at Enron, Global Crossing, Worldcom, and other companies have highlighted the need for change. The Sarbanes-Oxley Act of 2002 and the New York Stock Exchange revised listing guidelines have responded to this need primarily through new regulations for publicly-traded companies. In particular, our post-Enron corporate governance regime will rely more heavily on independent directors as a source for wise decisionmaking. In this Reply, we present some evidence from the takeover arena suggesting that exclusive reliance on the independent directors may be misplaced.

To address the problems we face today, it would be helpful to place limits on the ability of boards to block hostile bids indefinitely. We have demonstrated in our original paper that the post-just say no effective staggered board has severely reduced the pressure that the market for corporate control can exert on disloyal boards. Surprisingly, Gordon, ${ }^{100}$ Bainbridge, ${ }^{101}$ and Stout wish to provide directors with expanded and what we believe amounts to practically unlimited powers to block even offers that shareholders find attractive. The evidence that our work has put forward, reinforced by the striking corporate governance failures of the past year, clearly indicates that this would be a step in the wrong direction.

An important element of an improved corporate governance system would involve reviving the hostile takeover-not in its full and uncontrolled form (with T. Boone Pickens playing the monster to academia's Dr. Frankenstein), but as a responsible yet viable mechanism for achieving value-creating changes in corporate control. ${ }^{102}$ We believe that the approach we put forward in our original article, as developed further in this Reply, would be a moderate but important step toward such a solution, a step that in fact reflects the best understanding of existing Delaware jurisprudence.

100. See, e.g., Gordon, supra note 4, at 820 (defending our current takeover regime because the conventional wisdom "has come around to a pragmatic view that in the "real world,' the legal, practical, and economic considerations tend to even out in a rough justice sort of way").

101. See, e.g., Bainbridge, supra note 3, at 820 (posing the question, "Who decides?," as the premise for his article, which is far less interesting for the current policy debates than the question, "Who should decide?").

102. Cf. Herbert Grubel, Regulators vs. Adam Smith, Wall ST. J., Oct. 3, 2002, at A14 ("Throughout history... hostile takeovers were profitable because the board of directors installed by new owners would eliminate practices that caused share prices to be depressed. Thus, executives with excessive compensation are replaced, bonus and option plans adjusted and shady accounting and self-dealing eliminated."); Henry G. Manne, Bring Back the Hostile Takeover, Wall St. J., June 26, 2002, at A18 ("New scandals will continue until we bring back the most powerful market mechanism for displacing bad managers: hostile takeovers."). 